\title{
Alat Pendeteksi Logam Pada Makanan Berbasis Arduino UNO
}

\author{
Farhan Muhtarom ${ }^{1}$, Hansi Effendi ${ }^{2}$ \\ 1,2 Universitas Negeri Padang \\ Jl. Prof Dr. Hamka Air Tawar, Padang, Indonesia \\ farhanmuhtarom5@gmail.com ${ }^{1}$, hans 79@ft.unp.ac.id ${ }^{2}$
}

\begin{abstract}
Food is something that can be eaten by living things and after being digested and absorbed by the body will be useful for health and survival. The discovery of several metals in snack packaging makes these foods if consumed can harm the human body. Therefore, the food industries need to pay attention to food hygiene, especially for industries in medium and small businesses that rarely use this metal detector. In the previous design, this tool would work automatically to detect foods that were detected by metal and which were not detected by metal. Arduino uno is used as the control center of this tool, the metal sensor functions as a sensor that detects metal, the infrared sensor functions as detecting obstacles and counting the amount of metaldetected foods and those that are not detected by metal and the amount will be displayed on the LCD. From the tests that have been carried out, this tool works to detect metal in each food and separate foods that are detected by metal from those that are not detected by metal to a predetermined place
\end{abstract}

Keywords - Food, DC Motor, Arduino Uno, Metal Sensor, Infrared Sensor

Abstrak- Makanan adalah sesuatu yang dapat dimakan oleh makhluk hidup dan setelah dicerna serta diserap tubuh akan berguna bagi kesehatan dan kelangsungan hidup. Penemuan beberapa logam pada kemasan makanan ringan membuat makanan tersebut jika di konsumsi dapat membayahakan tubuh manusia. Maka dari itu, industri-industri makanan perlu memperhatikan kebersihan makanan tersebut baik itu terutama untuk industri dalam usaha menengah dan kecil yang jarang menggunakan alat pendeteksi logam ini. Pada perancangan sebelumnya, alat ini akan bekeeja secara otomatis mendeteksi makanan-makanan yang terdeteksi logam dan yang tidak terdeteksi logam. Arduino uno digunakan sebagai pusat kontoller dari alat ini, sensor logam difungsikan sebagai sensor yang akan mendeteksi logam, sensor infrared di fungsikan sebagai mendeteksi halangan dan menhitung jumlah makanan-makanan yang terdetesi logam dan yang tidak terdeteksi logam dan jumlah akan di tampil pada LCD. Dari pengujian yang telah dilakukan, alat ini bekerja mendeteksi logam di setiap makanan dan memisahkan makanan yang terdeteksi logam dengan yang tidak terdeteksi logam ke tempat yang telah ditentukan.

Kata kunci- Makanan, Motor DC, Sensor Logam, Sensor Infrared

\section{Pendahuluan}

Makanan adalah sesuatu yang dapat dimakan oleh makhluk hidup dan setelah dicerna serta diserap tubuh akan berguna bagi kesehatan dan kelangsungan hidup. [1]. Akhir-akhir ini kasus keracunan logam berat yang berasal dari bahan pangan semakin meningkat jumlahnya. Pencemaran lingkungan oleh logam berat dapat terjadi jika industri yang menggunakan logam tersebut tidak memperhatikan keselamatan lingkungan, terutama saat membuang limbahnya. Logam-logam tertentu dalam konsentrasi tinggi akan sangat berbahaya bila ditemukan didalam makanan.[2]

Kemajuan teknologi yang ada saat ini, mendorong kita untuk meng-gunakannya dalam segala bidang. Tujuannya ialah untuk memudahkan pekerjaan kita sekaligus meningkatkan produktifitas yakni efisiensi dan kualitas[3].

Pada industri makanan, baik industri kecil, menengah maupun besar, kebersihan dan kehigienisan makanan sangat perlu diperhatikan. Karena makanan yang tidak bersih dapat mengganggu kesehatan tubuh manusia. Hal ini perlu diperhatikan karena adanya beberapa kasus penemuan serpihan logam yang terdapat di dalam bungkus makanan ringan. Jika logam tersebut sampai tertelan, maka akan dapat menyebabkan gangguan kesehatan pada tubuh manusia. Segala upaya terus dilakukan untuk meningkatkan kesehatan tubuh manusia, baik itu di bidang kesehatan maupun di bidang teknologi agar membantu manusia menyadari untuk mengkonsumsi makanan yang bersih dan tidak mengandung bahanbahan yang membahayakan kesehatan.

\section{Motor DC(Power Window)}

Motor DC (power window) adalah motor yang mengubah energi listrik searah menjadi mekanis yang berupa tenaga penggerak torsi. Motor DC digunakan dimana kontrol kecepatan dan ketetapan torsi diperlukan untuk memenuhi kebutuhan.[4] 


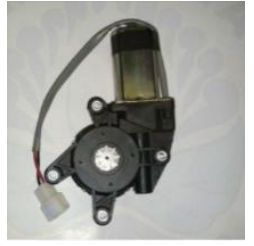

\section{Arduino Uno}

Arduino Uno adalah salah satu produk berlabel arduino yang sebenarnya adalah sebuah papan elektronik yang mengandung mikrokontroler ATMega328 (suatu keping yang secara fungsional bertindak seperti sebuah komputer). Mikrokontroler AVR seri Atmega328 yang merupakan produk dari Atmel yang terpasang pada arduino uno. Arduino memiliki kelebihan tersendiri dibanding board mikrokontroler yang lain selain bersifat open source, arduino juga mempunyai bahasa pemrograman sendiri yang berupa bahasa C.[5]

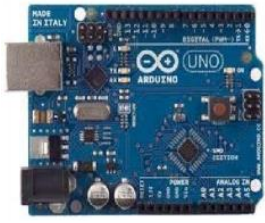

\section{DIY Metal Detector}

DIY Metal Detector merupakan sebuah modul yang terdiri dari beberapa komponen yang mampu mendeteksi adanya objek logam tanpa adanya kontak fisik,

\section{Sensor Infrared}

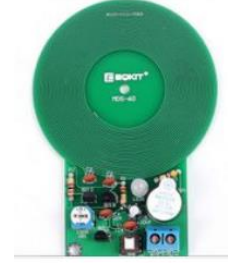

Konsep dasar dari sensor IR(infrared) yang digunakan untuk mendeteksi suatu benda adalah dengan cara mentrasmisikan sinyal infra merah (IR trasmiter) kemudian sinyal inframerah ini dipantulkan oleh permukaan suatu objek dan sinyal diterima oleh penerima inframerah (IR recevier).[6]

\section{Photodioda}

Photodioda adalah jenis dioda yang dapat berfungsi untuk mendeteksi cahaya. Berbeda dengan dioda biasa, komponen elektronik ini akan mengubah energi cahaya menjadi arus listrik. Photodioda adalah dioda yang bekerja berdasarkan intensitas cahaya, jika photodioda mendapatkan cahaya maka photodioda bekerja seperti dioda pada umumnya, namun jika tidak mendapatkan cahaya maka photodioda akan berperan seperti resistor dengan tahanan yang besar sehingga arus tidak dapat mengalir.[6]

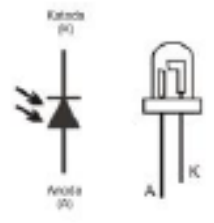

\section{DF Player Mini}

DF Player Mini adalah modul MP3 yang dapat langsung dihubungkan ke speaker Modul MP3 dengan baterai, power supply , speaker , keypad dapat digunakan sendiri , juga dapat dikontrol melalui port serial, modul Arduino Uno atau mikrokontroler seri .[7]

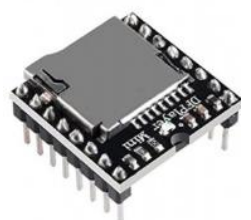

\section{IC ULN2803}

ULN 2803 adalah chip Integrated Circuit (IC) berupa rangkaian transistor Darlinton dengan tegangan tinggi Di sisi output ULN2803 umumnya berada pada selang nilai $50 \mathrm{~V} / 500 \mathrm{~mA}$, sehingga dapat mengoperasikan beban kecil secara langsung. [8]

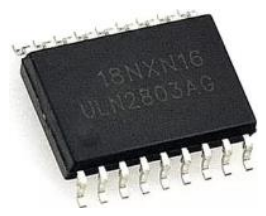

\section{Power Supply Swicthing}

Switching power supply atau yang lebih dikenal dengan switched mode power supply (SMPS), adalah catu daya elektronik yang terdiri darisebuah regulasi switching yang disediakan sesuai kebutuhan pada tegangan keluaran.[9]

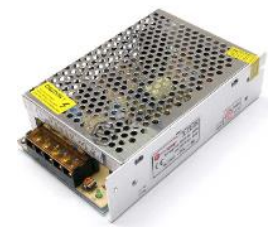

Relay

Relay adalah komponen elektronika berupa saklar elektronik yang digerakkan oleh arus listrik, relay merupakan tuas saklar dengan lilitan kawat pada batang besi (solenoid) di dekatnya. Ketika solenoid dialiri arus listrik, tuas akan tertarik karena adanya gaya magnet yang terjadi pada solenoid sehingga kontak saklar akan menutup.[4]

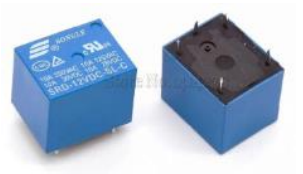




\section{LCD $4 \times 20$}

LCD (Liquid Crystal Display) atau display elektronik merupukan salah satu komponen elektronika yang memiliki fungsi untuk menampilkan suatu data, baik data tersebut berupa karakter, huruf, bahkan grafik sekalipun. LCD (Liquid Crystal Display) dibuat dengan menggunakan teknologi CMOS Logic yang bekerja dengan tidak menghasilkan cahaya tetapi hanya memantulkan cahaya yang berada di sekelilingnya terhadap Frontlight atau mentransimisikan cahaya dari Backlight.[10]

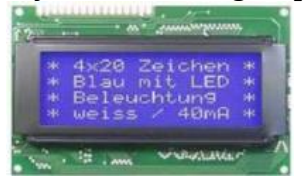

\section{METODE}

Pada bab ini akan membahas tentang perancangan hardware dan software yang terdiri dari blok diagram, perancangan mekanik dan flowchart.

\section{Blok Diagram}

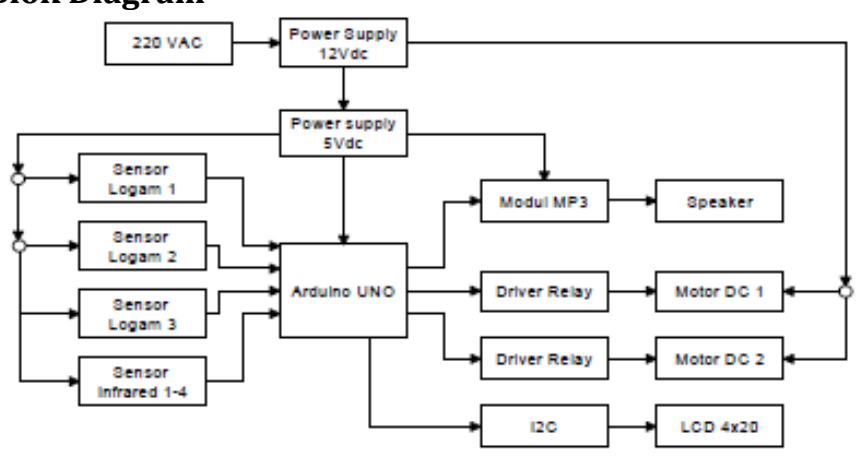

Gambar 1. Blok Diagram Keseluruhan

Berdasarkan blok diagram keseluruhan sistem di atas, fungsi dari masing-masing blok diagram sebagai berikut:

\section{Arduino UNO}

Merupakan bagian yang berfungsi untuk memproses input yang dimasukan sensor dan menghasilkan output berupa aktifasi pada motor DC dan modul MP3.

2. Sensor Logam

Merupakan sensor yang difungsikan untuk mendeteksi logam atau bahan metal yang ada didalam bungkus makanan ringan.

3. Sensor Infrared

Merupakan sensor yang difungsikan untuk kemasan makanan ringan dalam penseleksian tempat kemasan terdeteksi logam atau tidak

4. Modul MP3 (DF Mini Player)

Merupakan entity output yang difungsikan sebagai media informasi berupa suara dari pendeteksian logam terhadap bungkus makanan ringan tersebut.

5. Speaker

Merupakan sebuah hardware yang akan mengeluarkan suara dari modul MP3 (DF Mini Player)
6. Driver Relay

Merupakan relay yang berfungsi untuk mengaktifkan motor DC

7. Motor DC

Merupakan motor yang berfungsi untuk menggerakan belt conveyor.

8. $\mathrm{I} 2 \mathrm{C}$

Merupakan modul yang berfungsi untuk memangkas jumlah pin yang terhubung dari arduino ke LCD

9. LCD (Liquid Crystal Digital) $4 \times 20$

Merupakan entity output yang difungsikan sebagai media informasi berupa tampilan setiap aktifitas sistem pensortiran makanan yang terdeteksi logam atau tidak terdeteksi logam

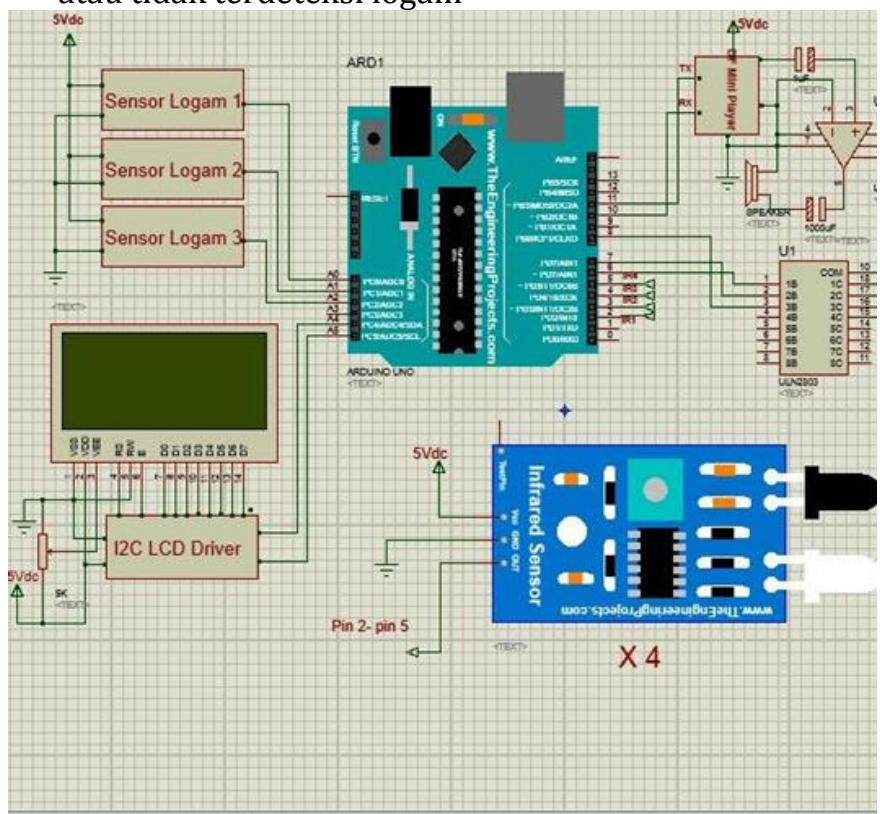

Gambar 2. Rangkaian Elektronika Keseluruhan

\section{Perancangan Mekanik(hardware)}

Perancangan mekanik hardware merupakan hal yang sangat penting dalam pembuatan tugas akhir ini. Karena dengan adanya hardware barulah sistem dapat diuji secara nyata apakah tugas akhir ini dapat bekerja dengan baik atau tidak. Rancangan hardware dari tugas akhir ini dapat dilihat seperti dibawah ini.

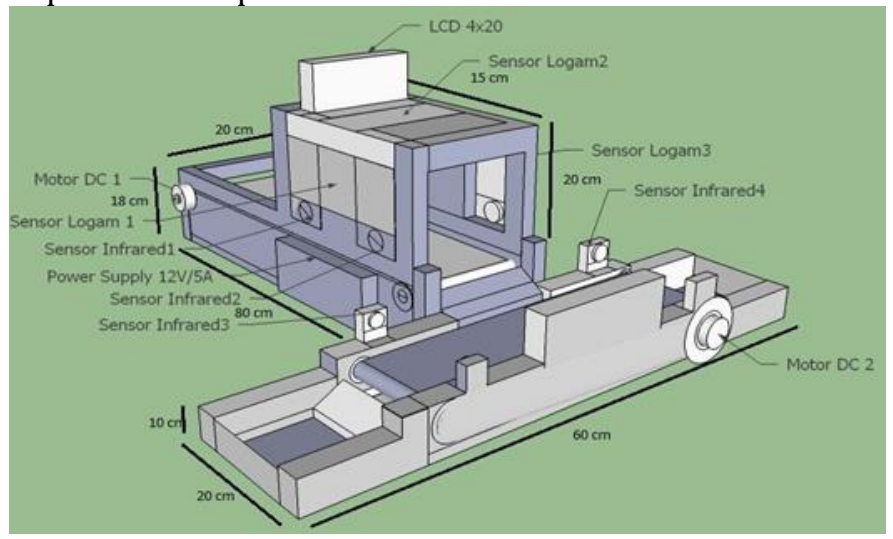

Gambar 3. Rancangan Hardware 


\section{Flowchart}

Flowchart adalah diagram alur pada perancangan program yang akan dibuat yang sesuai dengan prinsip kerja alat. Berikut adalah rancangan Flowchart Alat Pendeteksi logam Pada Makanan

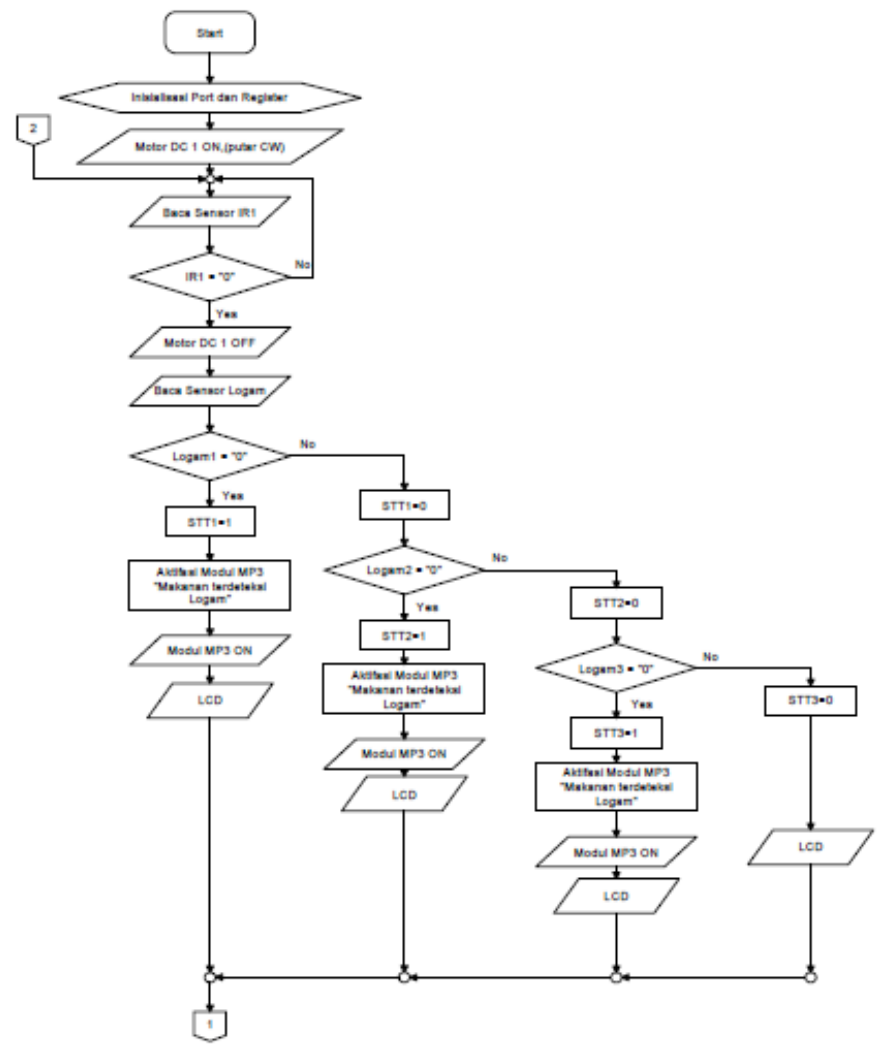

Gambar 4. Flowchart Alat Pendeteksi Logam Pada Pada Makanan

Setelah semua komponen terhubung dengan sumber dan kontroler maka alat dapat beroperasi. Diawali dengan berputarnya belt conveyor 1 searah jarum jam(CW) yang nantinya bergerak meimindahkan makanan kemasan tersebut pada proses pendeteksian. Makanan akan berjalan menggunakan belt conveyor 1, ketika makanan melewati sensor infrared 1 maka belt conveyor 1 berhenti, pada saat itu sensor DIY metal detector mendeteksi makanan apakah terdeteksi logam atau tidak. jika sensor mendeteksi logam pada kemasan makanan tersebut maka modul MP3 akan aktif dan speaker akan mengeluarkan suara("makanan terdeteksi logam").

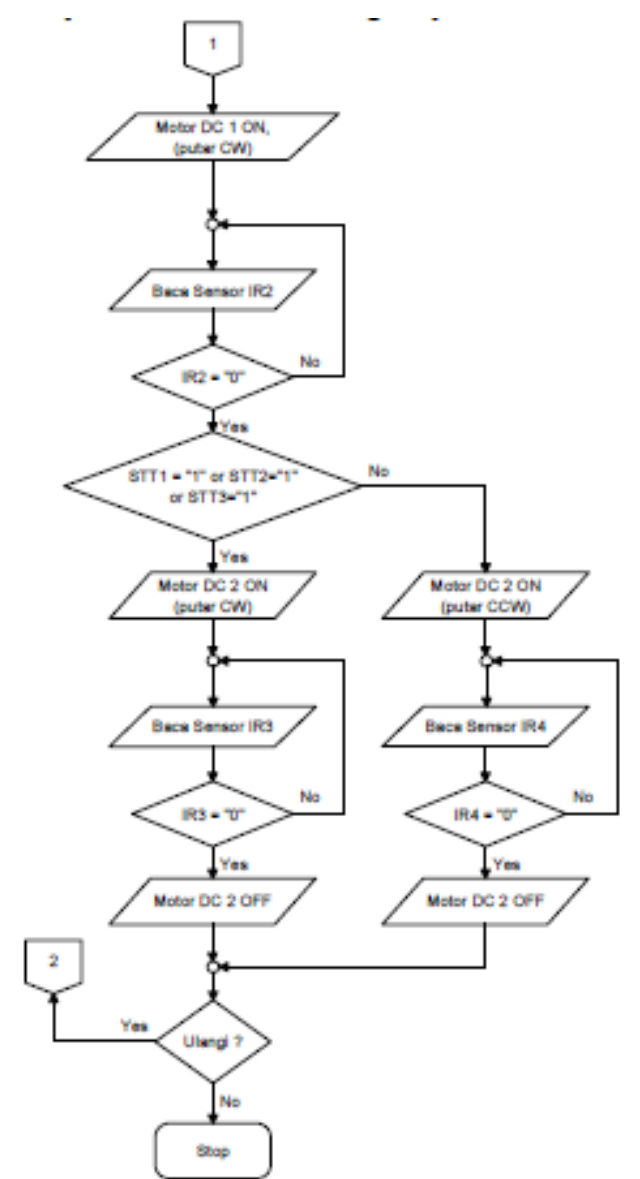

Gambar 5. Flowchart Alat Pendeteksi Logam Pada Makanan Lanjutan

Kemudian belt conveyor 1 berputar kembali, ketika makanan melewati sensor infrared 2, maka belt conveyor 1 mati kembali dan makanan jatuh ke belt conveyor 2 . Jika makanan tadi terdeteksi logam maka belt conveyor 2 akan berputar searah jarum jam (CW) menuju wadah yang telah ditentukan dan tampilan LCD akan bertambah pada bagian TL(Terdeteksi Logam). Ketika makanan melewati sensor infrared 4 maka belt conveyor 2 akan mati kembali. Apabila makanan tadi tidak terdeteksi logam maka belt conveyor 2 akan berputar berlawanan arah jarum jam (CCW) menuju wadah yang telah ditentukan dan tampilan LCD akan bertambah pada bagian TTL (Tidak Terdeteksi Logam). Ketika manan tersebut telah melewati sensor infrared 3 maka belt conveyor 2 akan mati kembali.

\section{HASIL DAN PEMBAHASAN}

Pengujian alat dilakukan untuk mengetahui apakah alat yang dibuat bekerja dengan baik atau tidak. Adapun beberapa pengujian yang penulis lakukansebagai berikut.

1. Pengujian Catu Daya

Pengujian dilakukan untuk tegangan masukan power supply dan tegangan keluaran 5VDC dan 12VDC dari catu daya tersebut. Berikut hasilnya 
Tabel 1. Hasil Pengujian Catu Daya

\begin{tabular}{|c|c|c|}
\hline No & Parameter Yang Diukur & $\begin{array}{c}\text { Hasil } \\
\text { Pengukuran }\end{array}$ \\
\hline 1 & $\begin{array}{c}\text { Tegangan masukan } \\
\text { Power Pupply }\end{array}$ & 231 VAC \\
\hline 2 & $\begin{array}{c}\text { Tegangan Keluaran } \\
\text { Power supply swicthing }\end{array}$ & 12,34 VDC \\
\hline 3 & $\begin{array}{c}\text { Tegangan keluaran } \\
\text { Power Supply Step Down }\end{array}$ & 5,04 VDC \\
\hline
\end{tabular}

2. Pengujian Sensor Logam

Pengujian dilakukan dengan mengukur tegangan keluaran sensor. Berikut hasil pengukuran yang didapat

Tabel 2. Hasil Pengukuran Tegangan Sensor Logam

\begin{tabular}{|c|c|c|c|}
\hline No & Parameter & $\begin{array}{c}\text { Hasil } \\
\text { Pengukuran }\end{array}$ & Kondisi \\
\hline 1 & VCC & 4,73 VDC & - \\
\hline 2 & Vout & 1,73 VDC & $\begin{array}{c}\text { Tidak terdeteksi } \\
\text { logam }\end{array}$ \\
\hline 3 & Vout & 4,23 VDC & Terdeteksi logam \\
\hline
\end{tabular}

3. Pengujian Sensor Infrared

Pengujian dilakukan dengan mengukur tegangan keluaran sensor. Berikut hasil pengukuran yang didapat.

Tabel 3. Hasil Pengukuran Tegangan Sensor Infrared

\begin{tabular}{|c|c|c|c|}
\hline No & Parameter & $\begin{array}{c}\text { Hasil } \\
\text { Pengukuran }\end{array}$ & Kondisi \\
\hline 1 & VCC & 4,74 VDC & - \\
\hline 2 & Vout & 0,11 VDC & $\begin{array}{c}\text { Tidak terdeteksi } \\
\text { halangan }\end{array}$ \\
\hline 3 & Vout & 4,73 VDC & $\begin{array}{c}\text { Terdeteksi } \\
\text { halangan }\end{array}$ \\
\hline
\end{tabular}

4. Pengujian Motor DC

Pengujian dilakukan dengan megukur tegangan, arus dan kecepatan motor. Berikut hasil pengukuran yang didapat.

Tabel 4. Hasil Pengukuran Tegangan, arus dan kecepatan Motor

\begin{tabular}{|c|c|c|c|c|}
\hline No & Kondisi & Tegangan & Arus & Kecepatan \\
\hline 1 & Hidup & 12,37 Volt & $1,59 \mathrm{~A}$ & $112 \mathrm{rpm}$ \\
\hline 2 & Mati & 0 Volt & $0.01 \mathrm{~A}$ & $0 \mathrm{rpm}$ \\
\hline
\end{tabular}

\section{Pengujian Modul MP3}

Pengujian dilakukan dengan mengamati suara yang dikeluarkan speaker ketika sensor mendeteksi adanya logam yang terdapat di dalam kemasan makanan. Adapun berikut dari hasil pengujian dari rangkaian modul MP3 dapat dilihat pada tabel dibawh ini

Tabel 5. Pengujian Modul MP3

\begin{tabular}{|c|c|c|}
\hline No & Kondisi Sensor & Keterangan \\
\hline 1 & Mendeteksi Logam & Aktif \\
\hline 2 & Tidak Mendeteksi Logam & Tidak Aktif \\
\hline
\end{tabular}

6. Pengujian Tampilan LCD

Pengujian ini dilakukan untuk melihat tampilan LCD ketika sensor mendeteksi makanan-makanan tersebut. Berikut tampilan LCD ketika makanan terdeteksi logam dan tidak terdeteksi logam.

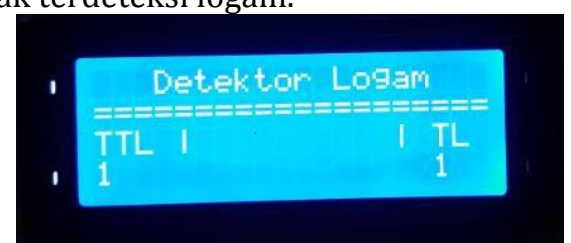

Gambar 6. Pengujian Tampilan

LCD

Dari hasil pengukuran dari beberapa rangkaian yang telah dilakukan pada catu daya, sensor logam, sensor infrared dan motor DC, setelah dibandingkan dengan data sheet komponen hasil yang didapat masih didalam rentangan tegangan kerja dari komponen-komponen tersebut

\section{PENUTUP}

Berdasarkan dari pengujian yang dilakukan diatas maka dapat disimpulkan bahwa alat pendeteksi logam pada makanan ini sudah bekerja dengan baik. Namun, sedikit saran untuk peneliti selanjutnya yaitu penambahan mekanisme pengepakan terhadap makanan-makanan yang tidak terdeteksi logam dan untuk mekanisme pemisahan makanan yang terdeteksi logam menggunakan mekanisme yang lebih efektif seperti system penumatic.

\section{REFERENSI}

F. Ardiani, "Perilaku Produsen Keripik Industri Rumah Tangga Di Tanjung Morawa Kabupaten Deli Serdang Tentang Label Makanan Tahun 2012."

T. Agustina, "Kontaminasi logam berat pada makanan dan dampaknya pada kesehatan," TEKNOBUGA J. Teknol. Busana dan Boga, vol. 1, no. 1, 2014.

A. Atmiasri and S. Rochman, "Pendeteksi Logam Untuk Industri Makanan Berbasis PLC," WAKTU, vol. 9, no. 1, pp. 78-81, 2011.

A. R. Riananda, "Rancang Bangun Alat Konveyor Dengan Sistem Kontrol Pengisian Air Minum Ke Dalam Botol Berbasis Mikrokontroler Atmega 16."

G. Gita Yudiasmara, "Rancang Bangun Alat Pemilah Benda Logam Dan Bukan Logam Otomatis Dengan Sensor Proximity Berbasis PLC (Programmable Logic Controller)." undip, 2018.

A. C. I. Tria Cahayaning, "Human Machine Interface (Hmi) Pada Simulasi Pemilahan Barang Berdasarkan Sensor Barang Yang Distempel Dan Jenis Barang Logam Non Logam Berbasis Programable Logic Controller (Plc) Schneider Modicon TM221CE16R." undip, 2018.

W. Hurisantri, "Sistem Pendeteksi Warna Dan Nominal Uang Untuk Penyandang Tuna Netra Berbasis Arduino Uno." Politeknik Negeri Sriwijaya, 2016.

M. E. SARI, "Sistem Dtmf Sebagai Pengendali Jarak Jauh Pada Rancang Bangun Perangkat Keras Alat Penghancur Sampah Organik Penghasil Pupuk Padat." Politeknik Negeri Sriwijaya, 2016.

I. M. Arifana, "Rancang bangun power supply switching dengan arus dan tegangan terkendali sebagai catu daya proses elektropleting logam." Universitas Islam Negeri Maulana Malik Ibrahim, 2016.

[10] M. I. Saputra, "Rancang Bangun Prototipe Alat Pengukuran Kecepatan Kendaraan Bermotor Menggunakan Sensor Efek Hall Seri A-1302 Berbasis Arduino Mega2560," 2020. 


\section{Biodata Penulis}

Farhan Muhtarom, lahir di Kuranji, 1 Februari 1998.Menyelesaikan studi DIV Teknik Elektro Industri pada Jurusan Teknik Elektro Fakultas Teknik Universitas Negeri Padang. ${ }^{[1]}$

Dr. Hansi Effendi, S.T., M.Kom., lahir di Batusangkar, 11 Februari 1979. Menamatkan studi Strata 1 (S1) di Jurusan Teknik Elektro Fakultas Teknik Universitas Andalas (UnAnd) Padang pada tahun 2001. Menamatkan studi Strata 2 (S2) di Program Pasca Sarjana Magister Ilmu Komputer Universitas Putra Indonesia (UPI) YPTK Padang pada Tahun 2009. Menamatkan studi Strata 3 (S3) di Program Pascasarjana Pendidikan Teknologi dan Kejuruan di Universitas Negeri Yogyakarta (UNY) pada Tahun 2015. Staf pengajar di Jurusan Teknik Elektro Fakultas Teknik Universitas Negeri Padang (FT-UNP) sejak tahun 2002. ${ }^{2}$ 